\title{
Preliminary hazard assessment and site characterization of Meşelik campus area, Eskişehir-Turkey
}

\author{
A. Orhan ${ }^{1}$, M. Turkoz ${ }^{2}$, and H. Tosun ${ }^{2}$ \\ ${ }^{1}$ Nevşehir University, Department of Geological Eng., Nevşehir, Turkey \\ ${ }^{2}$ Eskişehir Osmangazi University, Department of Civil Engineering, Eskişehir, Turkey
}

Correspondence to: A. Orhan (ahmet.orhan@nevsehir.edu.tr)

Received: 11 October 2012 - Revised: 11 December 2012 - Accepted: 12 December 2012 - Published: 18 January 2013

\begin{abstract}
Limited knowledge of ground conditions, such as geotechnical parameters, is one of the main causes of foundation failure. Unknown ground conditions can also cause additional burden costs. Due to lack of geotechnical parameters in foundation soil, some problems can be observed during and after the construction.

In this study, a comprehensive field study was conducted to make a preliminary hazard assessment on the Meşelik campus area, Eskişehir, Turkey. In this context, the experimental studies were performed in two stages. In the first stage, boreholes were drilled in the field; a standard penetration test (SPT) was performed and disturbed/undisturbed samples were collected from certain levels. In the second stage, laboratory tests were performed in order to identify and classify the samples. Unconfined compression strength and triaxial compression tests were conducted on undisturbed samples for determining the engineering characteristics. XRD (X-ray diffraction) tests were performed and the swelling potential of the samples were evaluated. The liquefaction potential of the area was also assessed on a SPT-based method. Thus, the geotechnical parameters and the liquefaction potential of the sub-surface in the study area were thoroughly analyzed and presented to be used for further studies.
\end{abstract}

\section{Introduction}

The Geographic Information System (GIS) is a high performance computer system used for collecting information on the natural events and phenomena occurring on the Earth surface. The collected data are digitally stored and examined by computers for mapping in desired format and scale analyzing. GIS has a large area of usage. In response to the emerging requirements, researchers and practitioners can use the software in accordance with their purposes by making various changes. GIS can be used in many geoscientific applications along with urban information systems, mathematical modeling and vehicle monitoring. Among these, some practices directed towards the geosciences can be listed as natural hazard analyses, studies with general geology purposes, and geotechnical studies (Wikle, 1991; Rackwitz, 2000; Dai et al., 2001; Orhan, 2005; Orhan and Tosun, 2010). Beside these, multiple approaches and methodologies have implemented into GIS to produce more accurate data, such as multicriteria decision analysis, fuzzy logic and artificial neural networks. GIS has been mostly used by geoscientists for determining landslides and landslide susceptibility zonation studies for over $10 \mathrm{yr}$. Chacon et al. (2006) have constituted a comprehensive study by creating engineering geological maps by means of landslide susceptibility. Liquefaction potential of an area can be ascertained by multi geo-data handling using multicriteria decision analysis (Kolat et al., 2006). Seismic zonation maps can also be created by GIS (Orhan et al., 2007; Tosun et al., 2007).

In recent years, GIS has been commonly used in the engineering geology solutions and geotechnical studies. In a study conducted by Karavul et al. (2006), they formed SPT(standard penetration test) based maps by using land survey reports of the municipality and private ones in parcel basis for the Adapazarı city center. Karavul et al. (2006) stated that these maps can be used for determining dynamic behavior of the Adapazarı region. Sert et al. (2006) have also conducted a study of the same region by creating SPT zonation maps to be used for geotechnical purposes. The present work summarizes the results of a study conducted to form a prototypical site that can be used for educational purposes 
(Tosun et al., 2001, 2002). The study was carried out using samples obtained from 22 different boreholes that have a total length of $372 \mathrm{~m}$ covering an area of $1.6 \mathrm{~km}^{2}$ in the Meşelik Campus of the Eskişehir Osmangazi University. Physical and mechanical data obtained both from SPT tests conducted on the terrain and the definition tests conducted on disturbed and undisturbed samples were transferred into the GIS environment, and then zonation maps at different depths were produced. Moreover, soil class and SPT cross-sections along three different directions were also drawn in order to fully evaluate the sub-surface in the area. Additionally, the liquefaction potential of the study area is evaluated using the SPT data.

\section{Study area}

Eskişehir basin is situated in the northwestern part of the Central Anatolia region and at the junction of both railway and highway transportation. The Eskişehir Osmangazi University consists of four different campuses which are distributed throughout the city. The Meşelik campus lying southwest in the city center is the main campus of the university. The study area located between 282.958-285.675 east longitudes and 4.402.185-4.403.947 north latitudes (Universal Transverse Mercator Zone 36, ED50) covers an area of about $1.6 \mathrm{~km}^{2}$ (Fig. 1). The Porsuk River in the northern section of the study area is the most important stream in the region, flowing through the city centre in an easterly direction. Medicine, engineering and architecture, science and letters, economics and administrative sciences and education faculties are situated in the campus area. The campus area includes a thirteen-story hospital and more than 30 educational buildings with 3-4 stories.

The campus area is located on mainly smooth topography surrounded by highlands south and north. The elevation of the region varies between 790-1010 m. Volcanic units, which are situated in south and southwest parts of the study area, comprise the highest elevations with up to $1010 \mathrm{~m}$ in height. A continental climate (semi-arid) of the Central Anatolia region is dominant in the study area. It is characterized by hot and dry summers, and cold and rainy/snowy winters.

The main campus area of the university has rapidly developed. There are several faculties and also many ongoing projects inside the campus. Figure 2 illustrates via aerial photos and a layout plan of 2010 the development of construction activities during 2002-2009.

\section{Geological setting}

Metamorphic, sedimentary, volcanic and ophiolitic rocks with ages ranging from Triassic to Quaternary are exposed in Eskişehir and its environs (Gözler et al., 1996). In the northern part of the area, serpentinites of the ophiolitic series of Triassic age are observed. The Eocene conglomerate of $70 \mathrm{~m}$

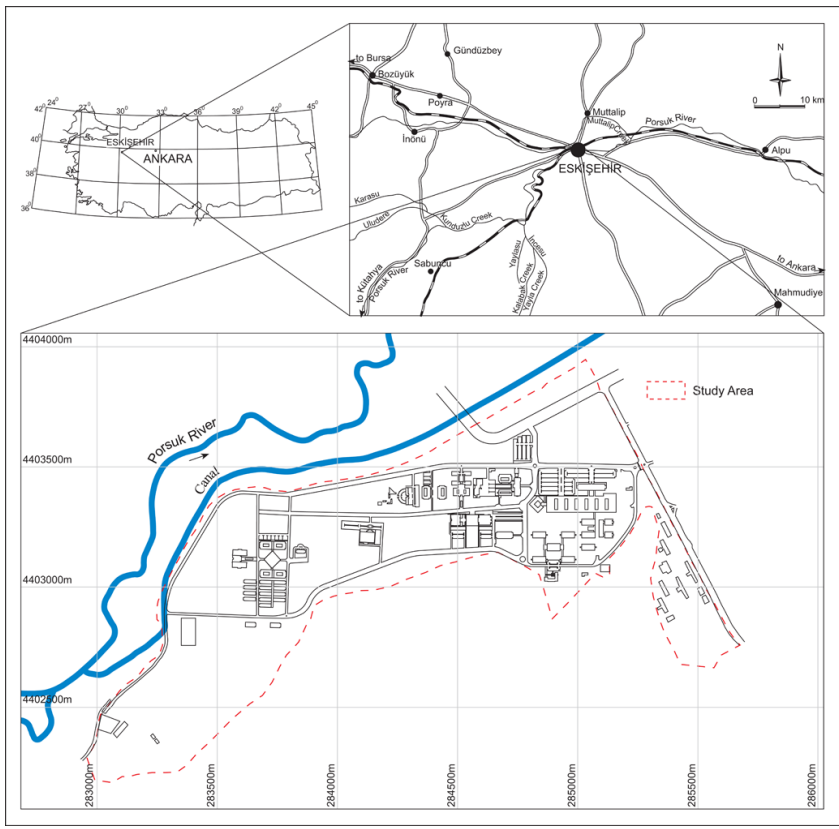

Fig. 1. Location map of the study area.

in width is generally found south of the study area. It is generally maroon-red in color and consists of sandstone-pebble stone alternations inclining to the south. Pliocene tuff-tuffite and basalts with a thickness of about $20 \mathrm{~m}$ overlie the conglomerates. Most parts of the study area are covered with alluvium, which consists of sediments in different sizes. The upper level of the study area is comprised of overburden soil with thickness of $5 \mathrm{~m}$, generally formed by disintegration and movement of the conglomerate in the brook beds. The geological and tectonic structures are given three-dimensionally in Fig. 3.

The largest earthquake occurring on the Eskişehir fault zone (EFZ) was the February 1956 earthquake with a magnitude of $M_{\mathrm{S}}=6.4$. Fault plane solution of the 1956 earthquake and field observations indicate that the EFZ, which played an important role in the development of Eskişehir and İnönü plains, is a transtensional fault zone (Altunel and Barka, 1998).

The structural formation of the region is generally controlled by oblique faults inclined in a northly direction. There are two faults in the study area, which are parallel to each other - the falling blocks of these faults also in a northly direction. It is estimated that there are also direction components along with the inclination components. An active fault in the northern section of the area passes through the city centre with an east-west direction and is considered as the earthquake source for the Eskişehir province (Altunel and Barka, 1998).

Figure 4 presents the peak ground acceleration map produced according to Boore et al. (1997), with main fault 


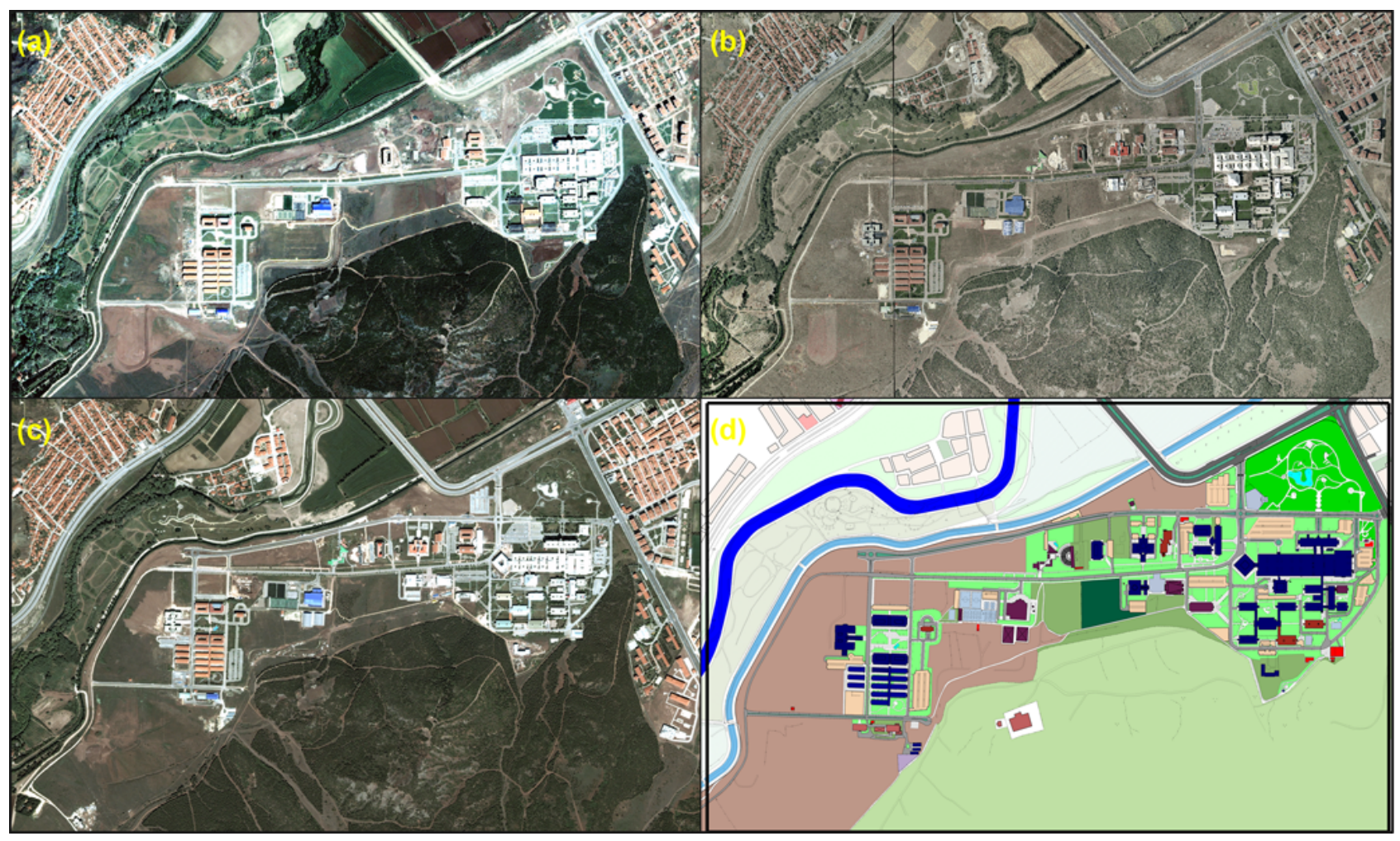

Fig. 2. General view of the campus area via aerial photos and layout plan: (a) Year 2002, (b) Year 2006, (c) Year 2009 and (d) Year 2010.

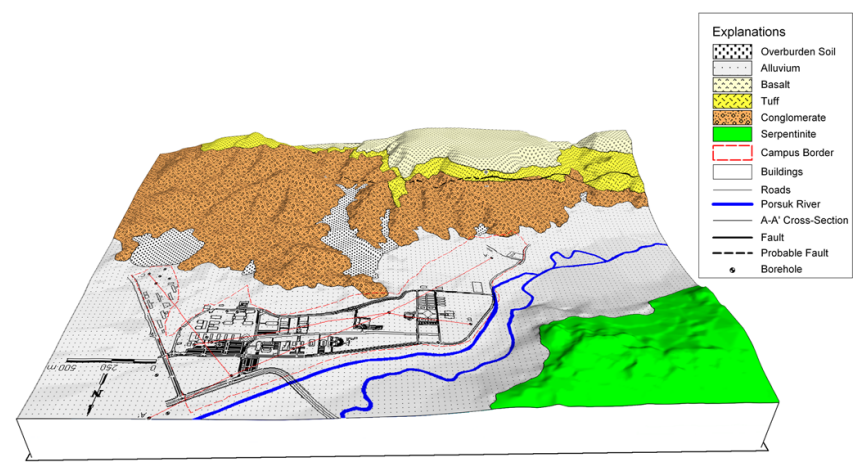

Fig. 3. Three-dimensional view of the study area.

systems and major earthquakes greater than 4 for Eskişehir City, modified from Orhan et al. (2007).

According to the borehole data, the groundwater is observed at some locations, its level is deeper than $8 \mathrm{~m}$ and its variation in the basin ranges between $0.1-1.5 \mathrm{~m}$. The groundwater level decreases towards the north to the Porsuk River. Noteworthy is that the drillings were performed in the dry season (i.e. July-August). The groundwater level during the rainy periods is observed in shallow depths.

\section{Experimental studies and method}

In order to define the soil units, both experimental studies in laboratory and field tests were performed, and according to these results the soil classifications were assigned and their layering properties were established. The field studies were performed in a restricted area especially on alluvium; the work details are described below.

The experimental studies within the scope of the study were performed in two stages. In the first stage, boreholes were drilled; standard penetration tests (SPT) were performed and disturbed/undisturbed samples were collected from certain levels. In order to obtain the soil profile, boreholes were drilled in 22 different locations, measuring a total length of $372 \mathrm{~m}$. During the studies, a total of 137 SPT tests were conducted, with 52 undisturbed and 137 disturbed samples collected for further experiments.

In the second stage laboratory tests were performed. Grain size analysis (ASTM D 422-63), consistency limit tests (ASTM D 4318-00) and specific gravity tests (ASTM D 85400) were carried out to identify and classify the samples. ASTM (1998) standard methods were followed during the preparation of samples, sampling, and testing. Unconfined compression strength and triaxial compression tests were conducted on undisturbed samples for determining the engineering characteristics of the samples. XRD (X-ray diffraction) tests were also performed on certain samples to identify 


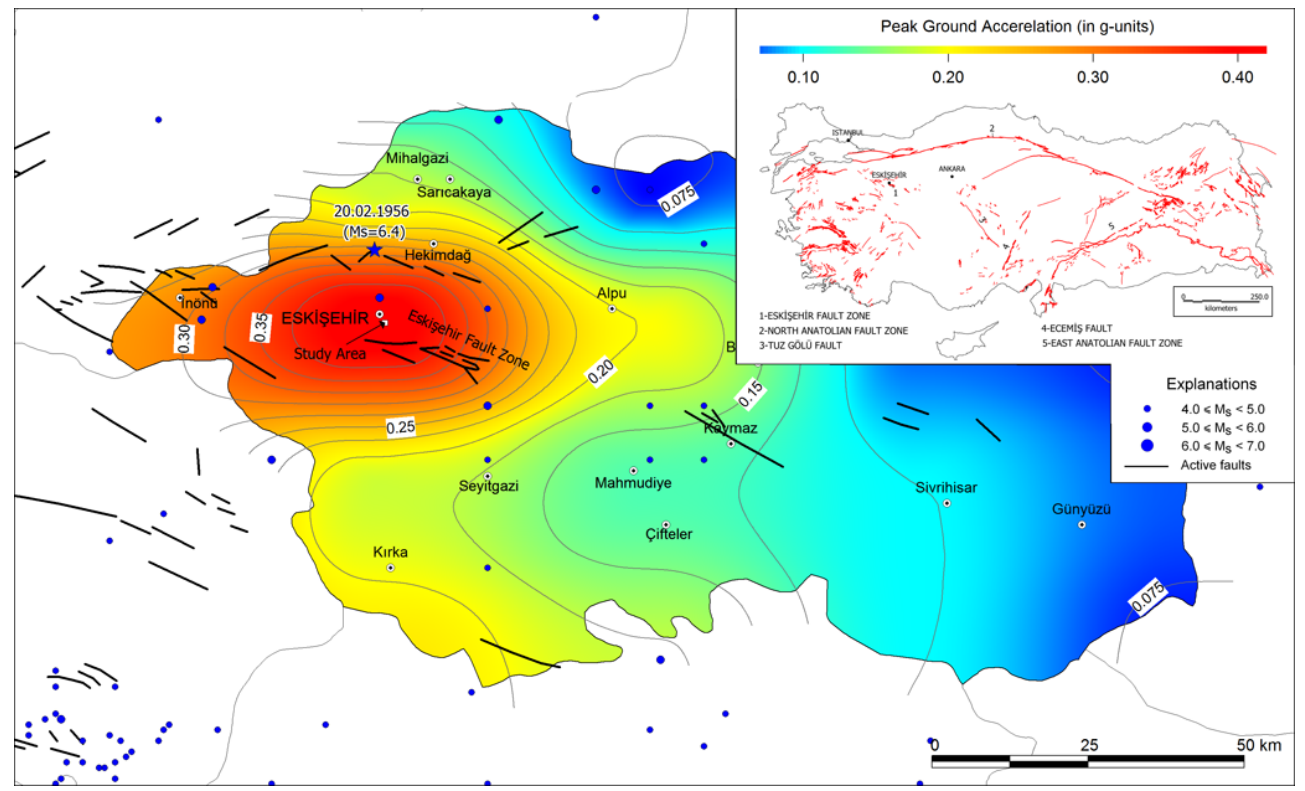

Fig. 4. Peak ground acceleration map, with main fault systems and major earthquakes greater than 4 for Eskişehir City (modified from Orhan et al., 2007).

the mineralogical composition. The liquefaction potential of the area was also evaluated applying a SPT-based method suggested by Youd et al. (2001). Some of the variables such as SPT and unconfined compressive strength were comparatively analyzed. Most of the data were on average to a depth of $10 \mathrm{~m}$ below the ground level. A summary of laboratory and field studies is given in Table 1 .

\section{Physical properties of the soils}

The physical properties of the soil samples were tested in the laboratory on undisturbed and disturbed samples that were collected from 22 boreholes, as mentioned previously. Sieve and hydrometer analyses, Atterberg limit determinations, water content and density on samples were carried out in accordance with the standards of ASTM (1998). Then, based on the test results, the samples were classified according to Unified Soil Classification System (USCS) (ASTM D 2487-00, 1998).

Most of the study area is covered with a soil identified as "alluvium", which consists of fine-grained soils in the upper levels and coarse-grained soils in the lower levels (see Fig. 3). The grain size distribution analyses showed that the samples are composed, on average, of $5 \%$ gravel, $38 \%$ sand and $57 \%$ fines (silt-clay). Although the liquid limit levels of the soil layers differ in a wide range, mainly the soils in the southern section are in low plastic character and can be classified as sandy-clayey silt and low plastic clay-silt (CL-ML) according to the USCS, while soils in the northern section (through the Porsuk River) are in high plastic character and can be classified as high plastic clay-silt (CH-MH). The statistical
Table 1. Summary of laboratory and field studies.

\begin{tabular}{llr}
\hline Study Type & Unit & Value \\
\hline Boreholes & amount & 22 \\
Total borehole length & meters & 372 \\
Disturbed samples & amount & 137 \\
Undisturbed samples & amount & 52 \\
SPT-N & amount & 137 \\
Definition tests & amount & 52 \\
Unconfined compression tests & amount & 51 \\
Triaxial compression tests & amount & 9 \\
XRD tests & amount & 8 \\
\end{tabular}

summary of test results is given in Table 2 . The grain size distribution interval of the fine-coarse grained soils and position of the samples on a plasticity chart are illustrated in Fig. 5.

The consistency limits of the samples in the study area are quite variable. The liquid limit values vary between $24-74 \%$ and the average is $48.9 \%$. The plasticity index of the same samples also widely varies (5-45), with the average value obtained being $23.7 \%$. According to these results, the soil samples consist mostly of clayey soils (CL-CH).

Coarse-grained soils consist of sand and gravel and build the bottom layer of alluvium; these dense soils could be mostly classified as well graded soils (SW-GW). These coarse samples are composed, on average, of $30 \%$ gravel, $58 \%$ sand and $12 \%$ fines (silt-clay). The fine content varies between $3-19 \%$ and is in non-plastic character. 
Table 2. Statistical summary of the definition test results.

\begin{tabular}{lrrrrr}
\hline & & \multicolumn{4}{c}{ Value } \\
\cline { 3 - 6 } \begin{tabular}{l} 
Soil \\
\cline { 3 - 6 } Properties
\end{tabular} & $\begin{array}{c}\text { Sample } \\
\text { Amount }\end{array}$ & Minimum & Maximum & Mean & $\begin{array}{r}\text { Std. } \\
\text { Deviation }\end{array}$ \\
\hline Grain Size Distribution & & & & & \\
\hline$<0.002 \mathrm{~mm}(\%)$ & 27 & 4.0 & 14.0 & 9.1 & 2.5 \\
$<0.075 \mathrm{~mm}(\%)$ & 82 & 28.0 & 83.0 & 57.3 & 13.6 \\
$<4.75$ mm (\%) & 82 & 68.0 & 100.0 & 95.4 & 7.06 \\
\hline Consistency Limits & & & & & \\
\hline Liquid limit (\%) & 80 & 24.0 & 74.0 & 48.9 & 11.9 \\
Plastic limit (\%) & 80 & 20.0 & 34.0 & 26.2 & 3.4 \\
Plasticity index (\%) & 80 & 5.0 & 45.0 & 23.7 & 10.1 \\
Water content (\%) & 80 & 3.1 & 37.7 & 21.0 & 8.6 \\
\hline
\end{tabular}
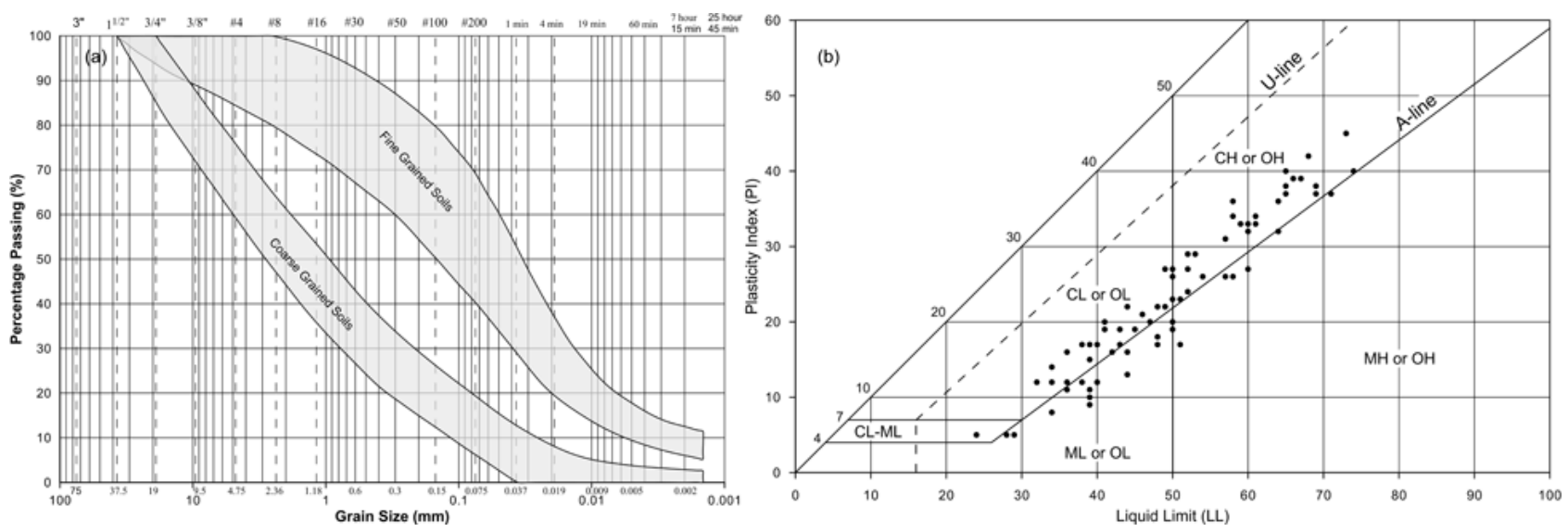

Fig. 5. Determination test performed on samples: (a) particle size distribution interval of fine-coarse grained soils and (b) position of the samples on a plasticity chart.

\section{Results and discussion}

As aforementioned, the obtained geotechnical data from the boreholes was evaluated by means of zonation maps and cross-sections in order to visualize the whole sub-surface. Work details are described below.

\subsection{Distribution of the soil layers}

In this study, the variations of the soil profile, in other words the layering properties of the alluvium, are evaluated in detail. Three different cross-sections are illustrated in Fig. 7, whose directions are illustrated in Fig. 6.

The units in the study area are divided into two main groups: Quaternary alluvium and Pre-Quaternary (Eocene) conglomerate. In order to evaluate the Alluvium in detail, it is also sub-grouped into 4 layers. These are from bottom to top; sand-gravel, high plasticity silt-clay, low plasticity silt-clay and clayey-silty sand. In some regions at the upper levels, vegetable soil with a thickness of $0.75 \mathrm{~m}$ is also

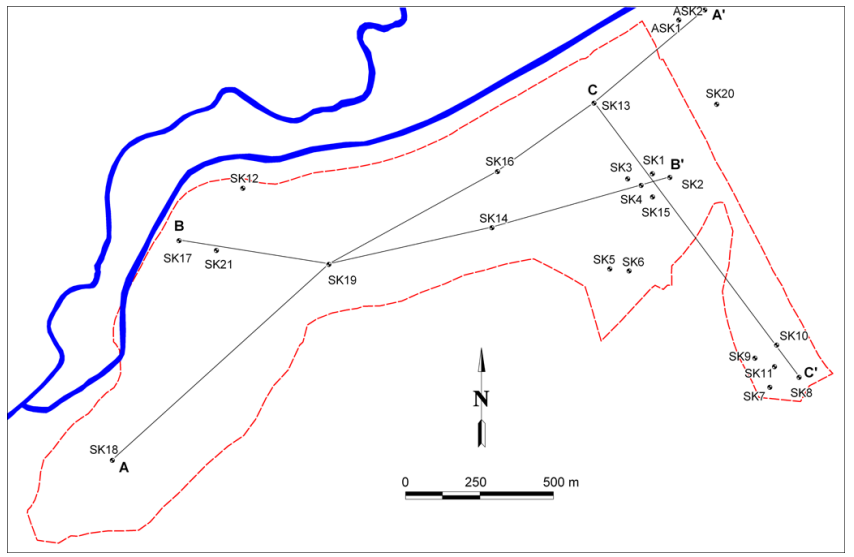

Fig. 6. Directions of cross-sections of the study area. 


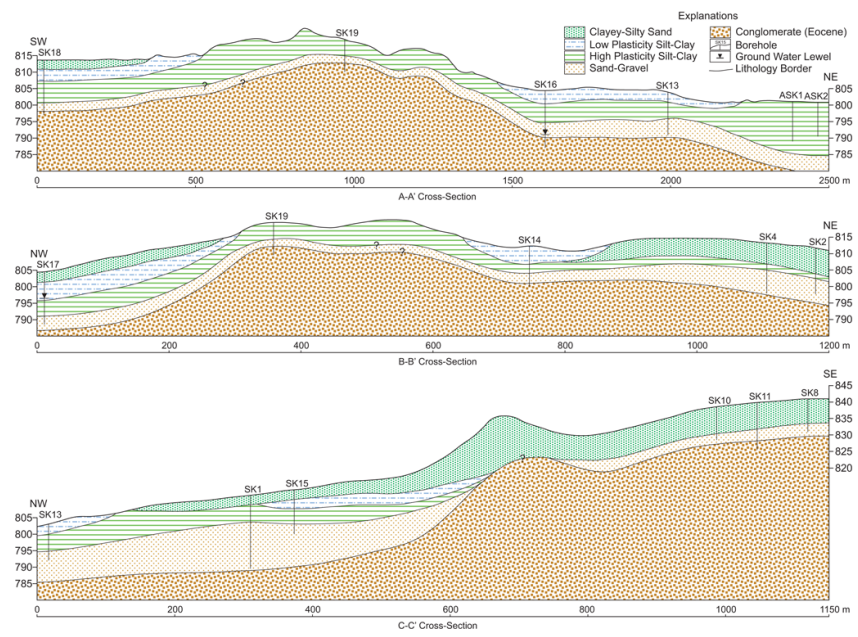

Fig. 7. Layering properties of the soils.

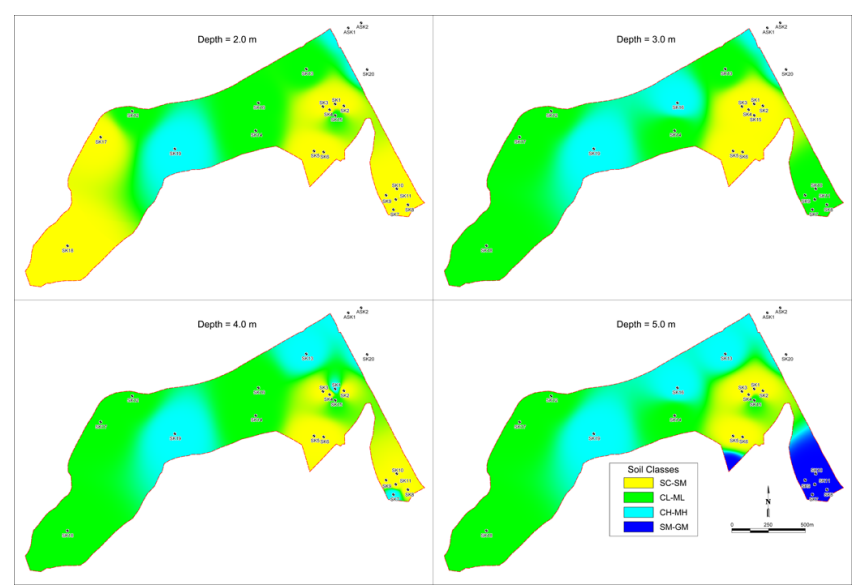

Fig. 8. Soil class zonation maps of the study area.

observed. Below this level the thickness of the clayey-silty sand reaches about $8 \mathrm{~m}$ and exhibits low- to non-plasticity index values and character. Under this layer, low plasticity clay is observed as small lenses and its thickness reaches about $5 \mathrm{~m}$ in some regions. Under this layer, high plasticity clay is observed and its thickness varies between 3-15 m. This layer shows mostly solid consistency, whereas in places close to the groundwater level it shows even liquid and plastic consistency. At the bottom, sand-gravel with a thickness around $10 \mathrm{~m}$ is observed. Noteworthy, as shown in Fig. 7, no groundwater was detected at any of the locations except one (SK 16). In general, in southwestern and central parts of the study area, high-plasticity clay was greatly detected and lowplasticity clay as small lenses was also observed in certain places. Beside the cross-sections, soil class zonation maps for certain depths were also constructed (Fig. 8) to evaluate the whole lithological variation in the study area.

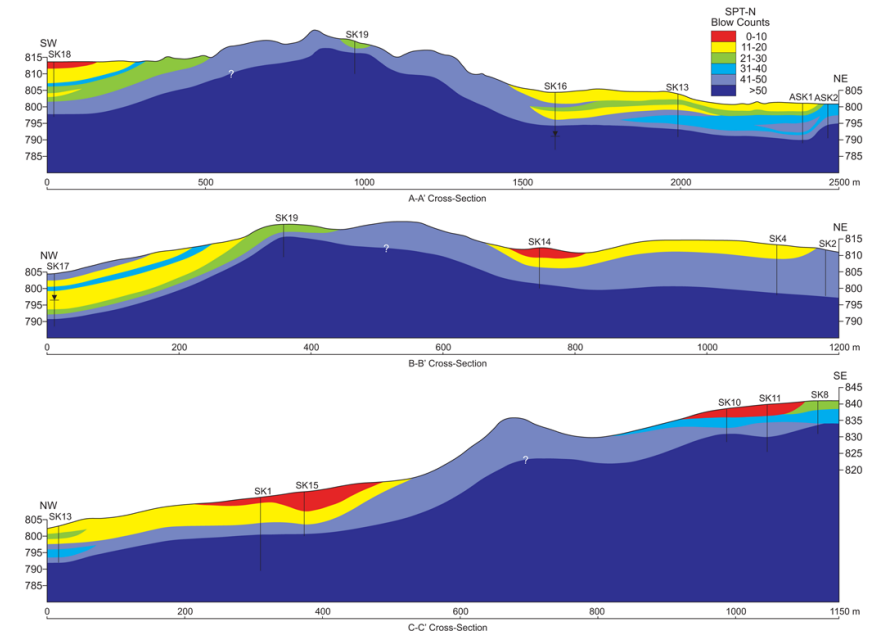

Fig. 9. SPT cross-sections created for the study area.

\subsection{Evaluation of the SPT blow count values}

As mentioned in the previous section in detail, throughout the study area different soil types were observed, and in order to evaluate the area, SPT was performed and profiles of the obtained values were drawn. It was recognized that these profiles are laterally correlated with each other. SPT crosssections at the same directions are also illustrated in Fig. 9. As shown in Fig. 8, the blow count is generally below 20, and it falls below 10 in some places. In topographically high regions, the number of blow counts generally ranges between 40 and 50. In general, it was observed that towards the northwest (towards the city center), moving closer to the Porsuk River, the number of blow counts decreased; whereas towards the basin border where conglomerates dominated, the number of blow counts increased.

Based on data from a total of 22 boreholes located in and around the study area, a database was formed in the GIS environment. All data from each borehole were input to the GIS as tabular data. Using these, zonation maps were produced for certain depths (i.e. 1.5, 3.5, 5.5 and $7.5 \mathrm{~m}$ ) (Fig. 10). It is seen that the SPT blow counts are low in the shallow depths, especially at depths between 1.5 and $3.5 \mathrm{~m}$; their numbers range between 10 to 20 and fall below 10 in certain places. The blow counts highly increase particularly at $3.5 \mathrm{~m}$ in the center of the area (SK19). This high value is attributed to the fact that the borehole at this location was performed in the residual soils and conglomerate level, which are formed with the alteration of conglomerate. The blow count is high at $1.5 \mathrm{~m}$ in the west part of the area whereas it decreases in deeper levels. The lowness of the related values is caused by the proximity of the Porsuk River. Moreover, blow counts of SPT increase through the depths in the eastern part of the area. It is considered that these regions are dominated by the conglomerate. 


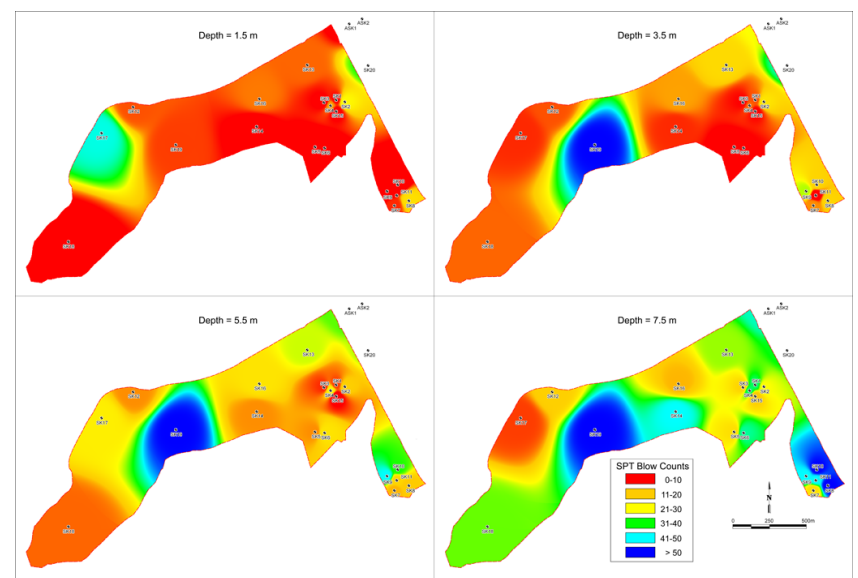

Fig. 10. SPT zonation maps performed in the study area.

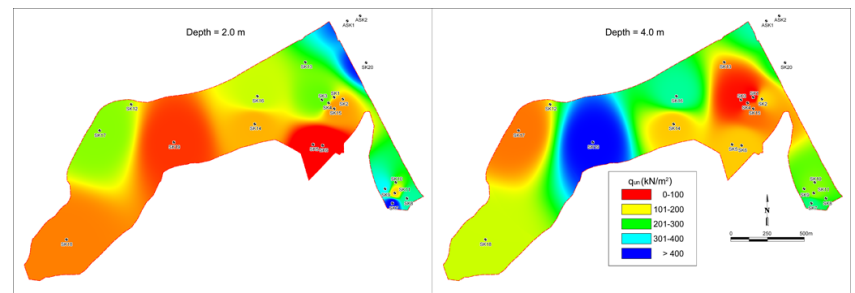

Fig. 11. Unconfined compressive strength zonation map of the study area.

\subsection{Evaluation of the unconfined-triaxial compressive strength values}

Throughout the study area both disturbed and undisturbed samples are collected for further experiments. Especially the disturbed samples are used for definition tests, whereas the undisturbed samples are used for determination of the mechanical properties of the soils, such as unconfined and triaxial compressive strength. The unconfined compression strength tests are only applicable to cohesive soils like triaxial tests and, although not as popular as the triaxial test, used where a rapid result is required (Smith, 2006). In this test, a laterally unsupported cylindrical specimen is subjected to a gradually increased axial compression load until failure occurs. For this study the unconfined and triaxial compression strength tests were performed only on undisturbed fine-grained soils according to ASTM D 2166 and ASTM D 2850 (1998), respectively, and their liquidity index was taken into consideration. All of the test samples are inorganic finegrained soils (silt-clay) and there is no crack and fissure observed in these cylinder shaped $(2: 1$, height : diameter) samples.

The variation of the unconfined compressive strength $\left(q_{\mathrm{un}}\right)$ values is investigated in certain levels (i.e. 2.0 and $4.0 \mathrm{~m}$ ). The zonation maps prepared for different depths based on uniaxial compressive strength are illustrated in Fig. 11.

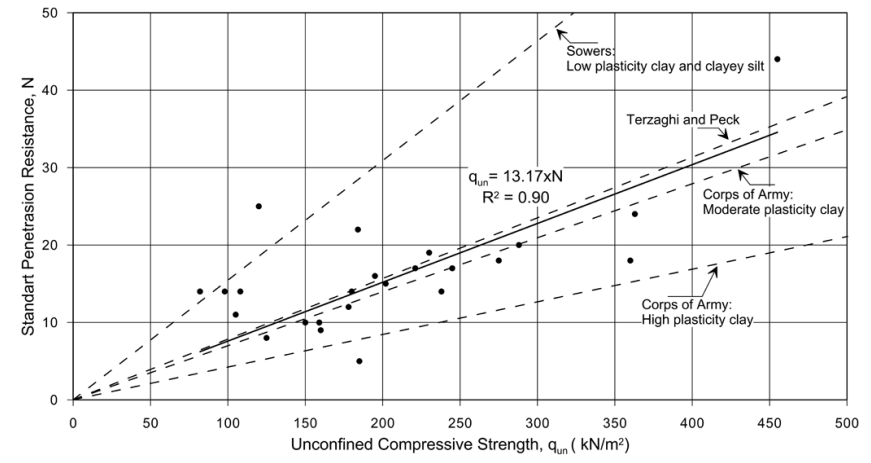

Fig. 12. Relationship between unconfined compressive strength and SPT (NAVFAC, 1982).

The unconfined compression strength tests were performed on 51 samples and the values obtained vary between $42-480 \mathrm{kPa}$ with the average of $234 \mathrm{kPa}$. The $q_{\text {un }}$ values are lower than $200 \mathrm{kPa}$ in the shallow depths, at the center and southwestern part of study area, and lower than $100 \mathrm{kPa}$ in certain parts. In the deeper levels, the $q_{\text {un }}$ values increase, only at some regions are the values less than $200 \mathrm{kPa}$, while the values in the center part of the campus area are found to be more than $400 \mathrm{kPa}$.

Beside the unconfined compression strength test, a triaxial compression strength test was also performed on some samples according to ASTM D 2850 (1998). The tests were performed at three different cell pressures (i.e. 100, 200 and $400 \mathrm{kPa}$ ) by means of an unconsolidated and undrained (UU) test procedure. For the test, nine samples from five different locations were used. The average shear strength $(\tau)$ and internal friction angle $(\varphi)$ were obtained as $300 \mathrm{kPa}$ and $13^{\circ}$, respectively.

Furthermore, the relation between SPT and $q_{\text {un }}$ values of fine samples was evaluated and compared with each other. For this aim, 24 values were used in the comparison and their liquidity index taken into account. To make a reliable comparison, both the $q_{\text {un }}$ and SPT values were determined using the values of the samples, which were almost all collected from the same depth. SPT and $q_{\text {un }}$ values vary between 5-44 and $82-455 \mathrm{kPa}$, respectively. The relation between them is illustrated in Fig. 12; the relation between SPT and $q_{\text {un }}$ values obtained from different researchers is also illustrated. As seen in Fig. 12, the correlation coefficient $\left(R^{2}\right)$ obtained is 0.90 . Thus, the equation can be said to be reliable and can be used for prediction of $q_{\text {un }}$ values.

\subsection{Evaluation of the XRD test results and swelling potential}

The XRD (X-ray diffraction) tests were performed on eight samples collected from different locations in the campus area. The average XRD results of the mineral compositions are illustrated in Table 3 and plotted in Fig. 13. According 
Table 3. Average mineral composition of the samples from the XRD results.

\begin{tabular}{crrrrrrrrrr}
\hline \multirow{2}{*}{$\begin{array}{c}\text { Sample } \\
\text { No }\end{array}$} & $\mathrm{Q}$ & $\mathrm{C}$ & $\mathrm{M}$ & $\mathrm{I}$ & $\mathrm{H}$ & $\mathrm{K}$ & $\mathrm{A}$ & $\mathrm{S}$ & $\mathrm{F}$ & $\mathrm{D}$ \\
\cline { 2 - 11 } & $5-8$ & $5-10$ & $40-43$ & - & $8-10$ & $10-15$ & - & - & $3-5$ & $10-15$ \\
1 & $3-6$ & $10-15$ & $40-43$ & - & $10-12$ & $12-16$ & - & - & $5-10$ & - \\
2 & $5-8$ & $10-15$ & $28-32$ & $12-15$ & $6-8$ & $6-8$ & - & - & $7-10$ & $8-10$ \\
3 & $28-32$ & $8-12$ & - & - & $15-18$ & $6-8$ & $10-15$ & $5-8$ & - & $8-13$ \\
4 & $3-6$ & $15-19$ & $23-28$ & $10-13$ & $6-8$ & $6-8$ & - & - & $5-7$ & $13-17$ \\
5 & $8-10$ & $10-15$ & $45-50$ & $8-10$ & $8-10$ & $8-10$ & $3-5$ & $3-5$ & - & - \\
6 & $8-10$ & $35-40$ & $25-30$ & $10-15$ & $8-10$ & - & - & - & - & - \\
7 & $5-12$ & $5-12$ & $30-38$ & $10-15$ & - & - & - & - & $3-7$ & $10-18$ \\
8 & & & & & & & -10 & -10 \\
\hline
\end{tabular}

* Q: Quartz, C: Calcite, M: Montmorillonite, I: Illite, H: Halloysite, K: Cordierite, A: Albite, S: Sanidine, F: Feldspar, D: Dolomite.

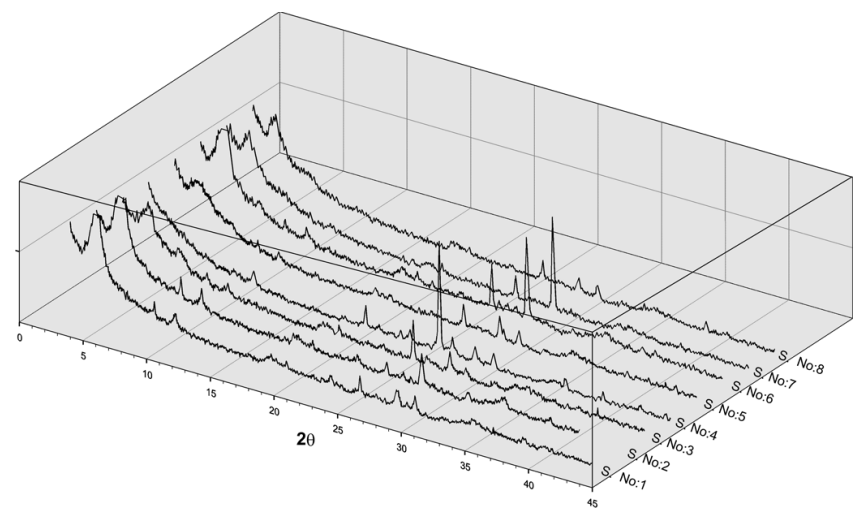

Fig. 13. XRD results of selected samples.

to the test results the dominant clay mineral type is illite and montmorillonite.

The swelling potential of samples with high abundance of montmorillonite plays a crucial role since they may especially affect lightweight and buried structures. Türköz (2006) conducted a series of experiments in the campus area to define the swelling clays and the factors acting on the swell mechanism. Türköz discusses the lime mixture for controlling the swell potential and introduces the results of a study performed on the performance of the hydrated lime-clay mixture for the samples collected from the study area. In that study, the samples were compacted at the standard and modified compaction energy levels, and then swell tests were carried out by considering lime-clay mixture at different percentages (i.e. $0,1,3$ and 5 percent by dry weight of soil). For this purpose, 88 specimens were used to measure the swelling potential. As a result of this experiment, it was shown that the stabilization of high plasticity clay can be sufficiently provided by the hydrated lime mixture and the significant effects on the mixtures are possible after 3 percent of the hydrated lime. It is also seen that lime mixture is more effective on the specimen series prepared when considering the modified energy level.

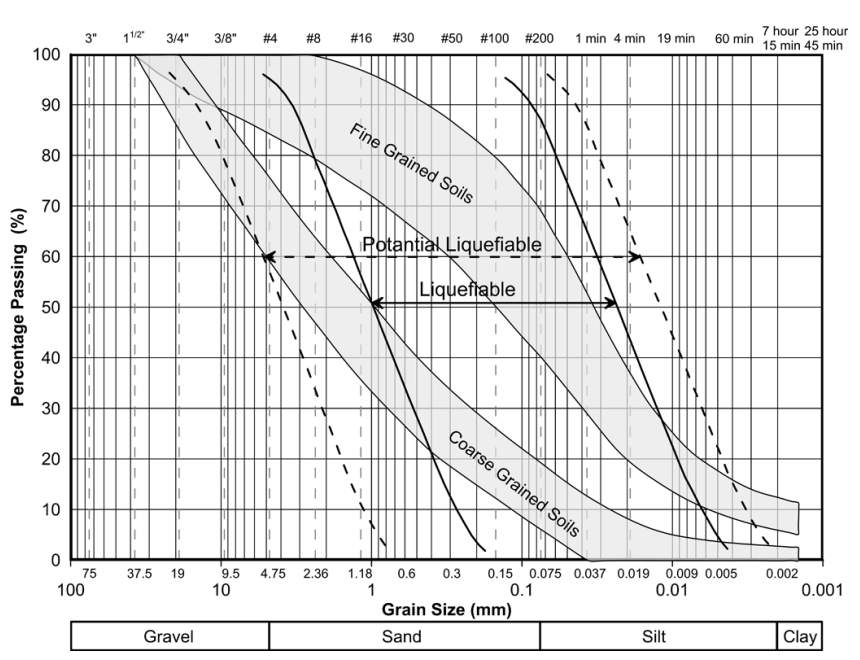

Fig. 14. Grain size distribution interval for liquefaction susceptibility of the soil samples.

\subsection{Evaluation of soil liquefaction}

Liquefaction susceptibility according to Iwasaki (1986) is illustrated in Fig. 14. As seen in this figure, the soil samples are grouped as fine- and coarse-grained soils and for effective presentation their lower and upper bounds for each sieve aperture is used.

In this study, the SPT-based method suggested by Youd et al. (2001) was performed. The liquefaction potential assessment was carried out with 47 SPT blow counts. A scenario earthquake magnitude of $M=6.4$, produced by the Eskişehir Fault Zone, was used in the calculations. Analyses were carried out at different seismic hazard levels as $0.19,0.30$ and $0.47 \mathrm{~g}$. Results of the analyses are presented with two different perspectives (Figs. 15 and 16). It should be noted that layers with $\mathrm{N}_{1(60)}$ values greater than 30 are not included in these analyses. Seed and Idriss (1971) proposed a simplified procedure termed the cyclic stress method. In this method, earthquake-induced loading characterized in terms of cyclic stress ratio (CSR) is compared to the liquefaction resistance 


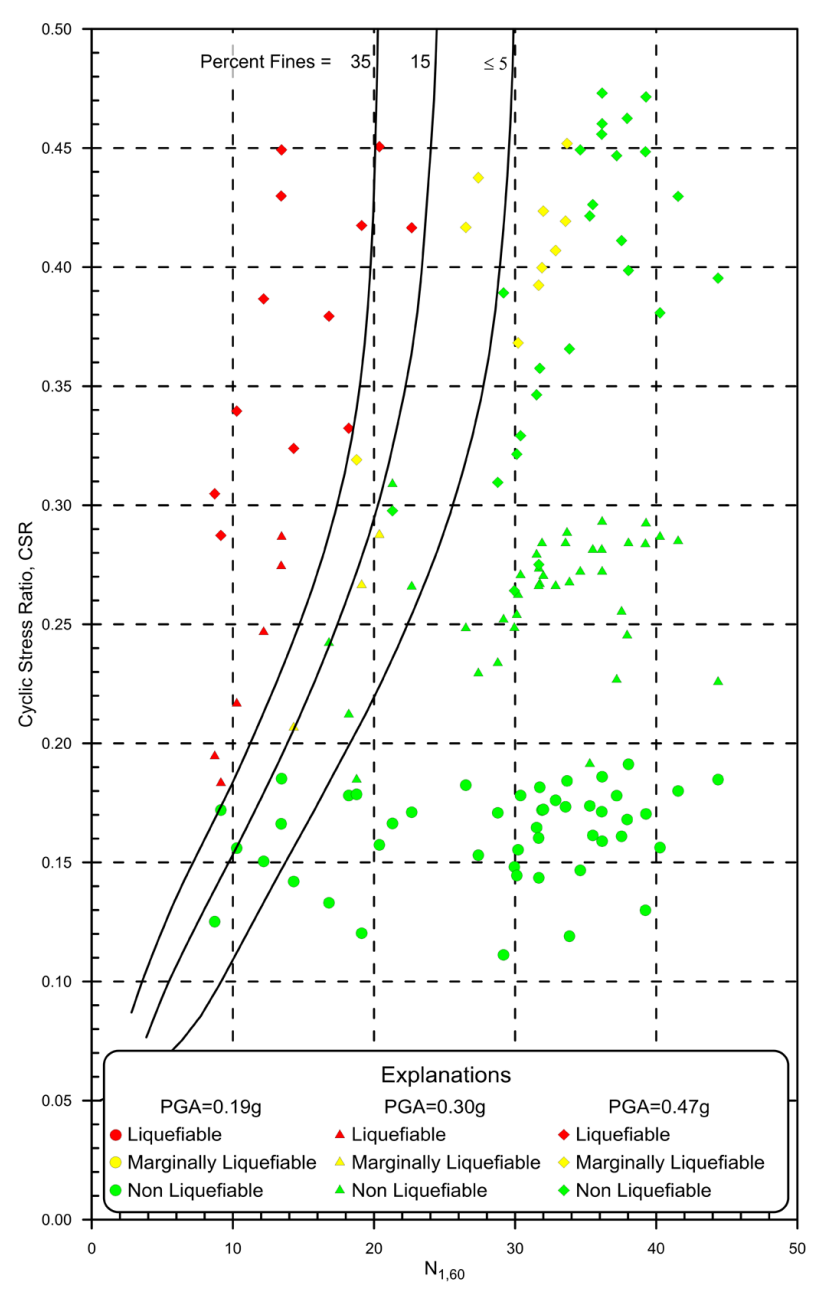

Fig. 15. Cyclic stress ratio and SPT $N_{1,60}$ plot based on Youd et al. (2001).

represented in terms of the cyclic resisting ratio (CRR). The details of CSR and CRR calculations are described in Tosun et al. (2011).

Generally, CRR curves represent the liquefaction susceptibility for a magnitude of 7.5. Because of using an earthquake with a magnitude of $M=6.4$, the factor of safety is multiplied with a magnitude scaling factor (MSF). Various empirical MSF values have been proposed (Youd et al., 2001). For this study, the MSF suggested by Seed and Idriss (1982) is used for analyses. We propose three definitions of factor of safety for liquefaction potential: liquefiable $(\mathrm{FS} \leq 1.0)$; marginally liquefiable $(1<\mathrm{FS} \leq 1.2)$; and nonliquefiable ( $\mathrm{FS}>1.2)$.

Figure 15 indicates that none of the samples are nonand marginally-liquefiable (for $0.19 \mathrm{~g}$ ). When peak ground acceleration is equal to $0.30 \mathrm{~g}, 80.9 \%$ of the samples are non-liquefiable, $6.4 \%$ marginally liquefiable and $12.7 \%$ of the samples are liquefiable. Under an acceleration of $0.47 \mathrm{~g}$, $53.2 \%$ of the samples are non-liquefiable, $21.3 \%$ marginally liquefiable and $25.5 \%$ of the samples are liquefiable.

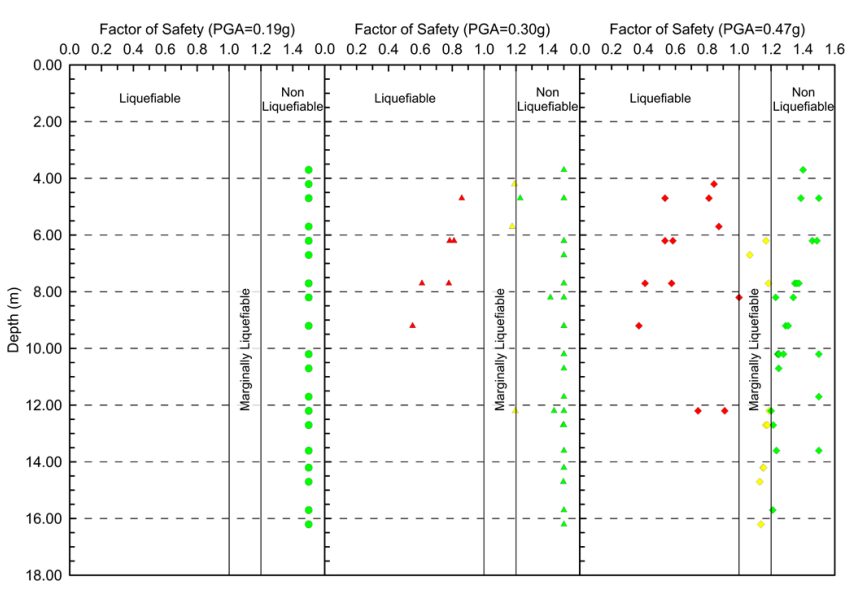

Fig. 16. Variation of safety factor versus liquefaction depth.

Figure 16 shows the variation of factor of safety with depth versus liquefaction. As seen in this figure, it is clear that most of the liquefiable and marginally liquefiable samples are in the range of 4-8 $\mathrm{m}$ depth below the ground surface.

\section{Conclusions}

In this study, geotechnical characteristics of the soils in the Meşelik Campus of Eskişehir Osmangazi University in the southwest of Eskişehir city center were determined. The field and laboratory test results were evaluated and illustrated by means of zonation maps and cross-sections. The results obtained in this study can be summarized as follows.

A database was created in the GIS environment using data both from the physical and mechanical data obtained from the SPT tests and laboratory tests on the disturbed and undisturbed samples. Using this database, zonation maps of different geotechnical parameters were produced for certain depths. Additionally, cross-sections of the SPT values and soil classes were also drawn in three different directions.

The soil profile exhibits an especially constant spreading. It starts with a vegetable soil layer at the top and continues with fine-grained soils. The fine-grained soils are laterally variable in some places; below this unit dense coarse-grained soils are observed. In the southern part of the study area, sedimentary rocks (Eocene aged conglomerate) are observed under the fine-grained soils.

Different types of geotechnical parameters such as SPT and $q_{\text {un }}$ values were compared and a reliable relation was found.

XRD tests were also performed on some samples in order to obtain the mineral composition of the soils. Results indicate that illite and montmorillonite are the dominant clay minerals, therefore special attention should be given to lightweight and buried structures.

Liquefaction potential of the area was evaluated according to a SPT-based model using different PGA values (i.e. 0.19, 
0.30 and 0.47$)$. It is observed that as the PGA values increase the ratio of liquefaction potential also increases and most of the samples, below $4 \mathrm{~m}$ and especially between 6 and $8 \mathrm{~m}$, are more susceptible for liquefaction.

In conclusion, it was shown that GIS programs can be effectively used in applications similar to the one outlined in this study. Each location in the campus area was evaluated and zonation maps and cross-sections from different soil properties (SPT values, soil type and unconfined compressive strength) were prepared to be used in further studies. In this respect, the whole sub-surface was fully visualized. It can be clearly seen that GIS can be used effectively in geotechnical investigations, but the data selection must be performed very carefully. It should be noted that the prepared illustrations are useful for generalized land-use planning purposes, although they may be less useful at a site-specific scale, where local geological properties change.

Acknowledgements. This study was supported by ESOGU Research Foundation Grant No: 199915015. Special thanks to the different local authorities who permitted the using of aerial photos of the study area.

Edited by: M. E. Contadakis

Reviewed by: two anonymous referees

\section{References}

Altunel, E. and Barka, A.: Neotectonic activity of Eskişehir fault zone between İnönü and Sultandere (in Turkish), Geol. Bull. Turkey, 41, 41-52, 1998.

ASTM: Construction: Soil and Rock (I), Annual Book of ASTM Standards, Vol. 04.08, ASTM Publication, Philadelphia, 1998.

Boore, D. M., Joyner, W. B., and Fumal, T. E.: Equations for estimating horizontal response spectra and peak acceleration from Western North American earthquakes, A summary of recent work, Seismol. Res. Lett., 68, 128-153, 1997.

Chacon, J., Irigaray, C., Fernandez, T., and El Hamdouni, R.: Engineering geology maps: landslides and geographical information systems, B. Eng. Geol. Environ., 65, 341-411, 2006.

Dai, F. C., Lee, C. F., and Zhang, X. H.: GIS-based geoenvironmental evaluation for urban land-use planning: A case study, Eng. Geol., 61, 257-271, 2001.

Gözler, M. Z., Cevher, F., Ergül, E., and Asutay, H. J.: The geology of middle and south Sakarya, MTA Report No 9973, Ankara, 1996 (in Turkish).

Iwasaki, T.: Soil liquefaction studies in Japan, State-of-Art, Soil Dynam. Earthq. Eng., 5, 2-68, 1986.

Karavul, C., Kurnaz, T. F., and Kiyak, A.: Creating the SPT (Standard Penetration Test) Maps of AdapazarıCity by Two Different Methods By Using GIS (Geographical Information System), Proceedings of the 4th GIS Days in Türkiye, 13-16 September 2006, Fatih University, İstanbul-Turkey, 2006.

Kolat, C., Doyuran, V., Ayday, C., and Suzen, M. L.: Preparation of a geotechnical microzonation model using Geographical Information Systems based on Multicriteria Decision Analysis, Eng. Geol., 87, 241-255, 2006.
NAVFAC DM-7.1: Soil Mechanics Design Manual, Department of the Navy, Naval Facilities Engineering Command, Alexandria, VA, USA, 348 pp., 1982.

Orhan, A.: The geo-engineering properties of foundation soils in southern part of Eskişehir city center and applying of geographic information system, Eskişehir Osmangazi Univertsity, Graduate School of Natural and Applied Sciences, Ph.D. thesis, 125 pp., 2005 (in Turkish).

Orhan, A. and Tosun, H.: Visualization of geotechnical data by means of geographic information system: a case study in Eskisehir city (NW Turkey), Environ Earth Sci., 11, 1071-1082, 2010.

Orhan, A., Seyrek, E., and Tosun, H.: A probabilistic approach for earthquake hazard assessment of the Province of Eskiş̧ehir, Turkey, Nat. Hazards Earth Syst. Sci., 7, 607-614, doi:10.5194/nhess-7-607-2007, 2007.

Rackwitz, R.: Reviewing probabilistic soils modeling, Comput. Geotech., 26, 199-223, 2000.

Seed, H. B. and Idriss, I. M.: Simplified procedure for evaluating soil liquefaction potential, J. Geotech. Eng., 97, 1249-1273, 1971.

Seed, H. B. and Idriss, I. M.: Ground motion and soil liquefaction during earthquakes, Earthquake Engineering Research Institute Monograph Series, Oakland, California, 134 pp., 1982.

Sert, S., Özocak, A. and Ural, N.: The Use of Geographical Information Systems for Geotechnical Purposes in Adapazar1, in: Proceedings of the 4th GIS Days in Türkiye, 13-16 September 2006, Fatih University, İstanbul-Turkey, 2006.

Smith, I.: Smith's Elements of Soil Mechanics, Blackwell Publishing, 8th Edn., 538 pp., 2006.

Tosun, H., Türköz, M., Orhan, A., and Çamdalı, B.: Geotechnical properties of Meşelik Clay, ESOGU Research Foundation Grant No 199915015, Eskişehir, 2001 (in Turkish).

Tosun, H., Türköz, M., Orhan, A., and Çamdalı, B.: The geotechnial properties of Eskişehir Meşelik Clay and its settlement suitability, Proceedings of the 9th National Symposium on Soil Mechanics and Foundation Engineering, Anadolu University, Eskişehir, 21-22 October 2002, 539-62, 2002 (in Turkish).

Tosun, H., Zorluer, İ., Orhan, A., Seyrek, E., Savaş, H., and Türköz, M.: Seismic Hazard and Total Risk Analyses for Large Dams in Euphrates Basin, Turkey, Eng. Geol., 89, 155-170, 2007.

Tosun, H., Seyrek, E., Orhan, A., Savaş, H., and Türköz, M.: Soil liquefaction potential in Eskis,ehir, NW Turkey, Nat. Hazards Earth Syst. Sci., 11, 1071-1082, doi:10.5194/nhess-11-10712011, 2011.

Türköz, M.: Stabilization of swelling clays with lime admixture and an application to the Eskişehir Meşelik clays, J. Eng. Arch. Fac., Eskişehir Osmangazi University XIX (2), 75-88, 2006 (in Turkish with English abstract).

Wikle, T. A.: Computers, maps and geographic information systems, National Forum, Summer91, 71, 37-39, 1991.

Youd, T. L., Idriss, I. M., Andrus, R. D., Arango, I., Castro, G., Chrstian, J. T., Dobry, R., Finn. W. D. L., Harder, L. F. Jr., Hynes, M. E., Ishihara, K., Koester, J. P., Liao, S. S., Marcuson, W. F., Martin, G. R., Mitchell, J. K., Moriwaki, Y., Power. M. S., Robertson, P. K., Seed, R. B., and Stokoe, K. H.: Liquefaction resistance of soils, Summary report from the 1996 NCEER and 1998. NCEER/NSF workshop on evaluation of liquefaction resistance of soils, ASCE J. Geotech. Geoenviron. Eng., 127, 817833, 2001. 